\title{
ECONOMIC DETERMINISTIC ANALYSIS OF TWO YEARS OLD STEERS PRODUCTION SYSTEMS
}

\section{ANÁLISE ECONÔMICA DETERMINÍSTICA DE SISTEMAS DE PRODUÇÃO DE NOVILHOS DE DOIS ANOS}

\author{
Mozer Manetti de Ávila ${ }^{1^{*}}$ \\ Paulo Santana Pacheco ${ }^{1}$ \\ Leonir Luiz Pascoal ${ }^{1}$ \\ 'Universidade Federal de Santa Maria, Santa Maria, RS, Brasil. \\ *Author for correspondence - avilazootec@gmail.com
}

\begin{abstract}
The objective of this study was to realize the economic deterministic analysis of steers production system in full cycle, finished in feedlot or cultivated pasture at twenty-four months old, utilizing or not the quality bonus from slaughterhouses. The study was realized using data from meta-analytic survey of studies in the central region of Rio Grande do Sul state, Brazil, in Microsoft Excel ${ }^{\circledR}$ spreadsheets. The systems were simulated considering the male and female calves weaned early, at the tree months of age, and finished at the 24 months of age in feedlot or cultivated pasture. After the slaughter, it was realized the economic deterministic analysis. According to financial return indicators net present value (NPV), benefit:cost index (IB:C) and additional return on investment (ROI) only the system in pasture show return at the end of planning horizon, and the internal return rate (IRR), modified internal return rate (MIRR) and discounted payback (PBd), show that this system possesses a higher risk of investment. The feedlot system show negative results as a investment project. The bigger cost center was depreciation, feeding supply and taxes, and the quality bonus shows up an interesting alternative of return, but was not sufficient to render the feedlot system a viable project.
\end{abstract}

Keywords: bioeconomic; economic indicators; economic viability; productive systems; risk analysis.

\section{Resumo}

O objetivo deste estudo foi realizar a análise econômica determinística do sistema de produção de novilhos em ciclo completo, terminados em confinamento ou pastagem cultivada aos 24 meses de idade, utilizando ou não a bonificação por qualidade das empresas frigoríficas. $\mathrm{O}$ experimento foi realizado utilizando dados via levantamento metanalítico de dados na região central do Rio Grande do Sul em planilhas do Microsoft Excel ${ }^{\circledR}$. Os sistemas foram simulados considerando os bezerros e bezerras desmamados precocemente, aos três meses de idade, e terminados aos 24 meses de idade em confinamento ou pastagens cultivadas. Após o abate, foi realizada a análise econômica determinística. De acordo com os indicadores financeiros de retorno valor presente líquido (VPL), índice benefício:custo (IB:C) e retorno adicional sobre o investimento (ROIA) somente o sistema de 
terminação em pastagem mostrou retorno ao final do horizonte de planejamento, e a taxa interna de retorno (TIR), taxa interna de retorno modificada (TIRM) e o payback descontado (PBd) mostraram que este sistema possui um elevado risco de investimento. O sistema em confinamento mostrou resultados negativos como um projeto de investimento. Os maiores centros de custos foram os gastos com depreciação, alimentação e impostos. A bonificação por qualidade se mostrou uma alternativa interessante de retorno, porém não foi suficiente para tornar o sistema de confinamento um projeto viável.

Palavras-chave: análise de risco; bioeconômico; indicadores econômicos; sistemas produtivos; viabilidade econômica.

Received on: February, $23^{\text {th }}, 2015$

Accepted on: August, 23 ${ }^{\text {th }}, 2017$

\section{Introduction}

In Rio Grande do Sul state there are currently consumer market niches looking for best quality meats, usually coming from younger animals, where generally the technological changes in livestock production systems suffer an intensification of production processes targeting this market.

In concern to optimize and facilitate the technical and economic performance of animals through nutrients consumption, Missio et al. ${ }^{(1)}$ suggest for example the supply of concentrated feed in feedlots. That presented as an alternative that reduces the age at slaughter enabling shorter production cycles $^{(2,3)}$ besides being a form of intensification of production ${ }^{(4)}$. While choosing the use of cultivated pastures, the restriction factor of the mated heifers at two years of age is the large dependence that cultivated winter pastures have of the weather conditions ${ }^{(5)}$. This information is corroborated by Martins et al. ${ }^{(6)}$ that mentions that productivity of forage grasses becomes one of the main factors responsible for the success of livestock. The pearl millet in summer ensures itself in systems that aim high productivity of forage and animal per area ${ }^{(7)}$ and the black oats, the Italian ryegrass and the leguminous plants present themselves as the main cultivars used to intensify production in winter, due to its ease of intercropping which generates a longer time of grazing for the animals ${ }^{(8)}$ besides offer suitable levels of weight gain ${ }^{(7)}$.

However, it is known that for the realization of intensified production cycle, investment in feed is necessary. According to Restle et al. ${ }^{(9)}$ this intensification usually results in higher investment and higher risks, because it comprises the combination of two segments: the efficiency of feed cost and efficiency for meat production. In this context, the producer runs into a number of alternatives that can make a project feasible or not feasible. Thus, the use of deterministic analysis through financial indicators show alternative ways to contribute to decision makers, by reducing the risks and uncertainties that arise with the alternatives, showing the short and long term viability of investment projects and which points of hindrance or major centers of impact on achieving its objective.

Souza and Clemente ${ }^{(10)}$ suggest the joint analysis of several financial indicators, targeting the confrontation between these possibilities of return on investment results, toward risk associated with the projects. Already for Kassai et al. ${ }^{(11)}$ thus the decision makers can monitor the actual performance 
of the project, check the short and long term if the expected returns will be realized and if show no evidence of discontinuity.

The objective of this study was to realize the economic deterministic analysis of steers production system in full cycle, finished in feedlot or cultivated pasture at twenty-four months old, utilizing or not the quality bonus from slaughterhouses.

\section{Material and Methods}

The present experiment was realized at Universidade Federal de Santa Maria, Rio Grande do Sul Brazil, in the period from March 2013 to July 2014. The systems were elaborated using data from meta-analytic survey of studies in the central region of Rio Grande do Sul state in Microsoft Excel ${ }^{\circledR}$ spreadsheets. There was collected the data referent at animal performance. A pastoral area of 500 hectares was considered, fully intended for livestock, with a herd already stabilized within the property, and the support capacity is considered as the minimum capacity of forage throughout the year. The simulation considered the calves and female calves weaned early, at the tree months of age, where it was withheld a total $100 \%$ of the males and $25 \%$ of females for the replenishment of breeding herd with the remaining being sold at this moment. Therefore, the categories that was marketed are female calves, cull cows and males yearlings.

After the weaning, the animals of the pasture system was considered reared in native pastures, where in the first and second winter the animals were placed in cultivated pastures composed by black oat (Avena strigosa Schreb.) intercropped with Italian ryegrass (Lolium multiflorum Lam.) until reach at 24 months of age. At this moment, the males were sold regardless of its weight and heifers were incorporated into the breeding herd.

In the feedlot system, the animals was considered weaned at three months directly in native pastures, where stay in the summer periods, and in the first winter was placed in cultivated pastures composed by black oat (Avena strigosa Schreb.) intercropped with Italian ryegrass (Lolium multiflorum Lam.) until November, and in the second winter were placed in feedlot for the finish, in a period of four months, receiving a diet composed of concentrate+roughage in the proportion 45:55 (Table 1).

For slaughter data, was considered a fixed carcass yield of 54\%, has been applied or not the bonus for quality. It was made considering the attribute table of the association of breed and the slaughterhouse, where the bonus of $8 \%$ was due to animals show the breed standard and fit into the category "two tooth" with carcasses weighing above $240 \mathrm{~kg}^{(12)}$.

Already for the financial indicators and estimation of production costs, it was considered the deterministic method, that assumes fixed values that are known to the items that compose the costs, taking as a basis average values practiced in the Rio Grande do Sul state during the period of March 2013 to March 2014. These data obtained for the identification of inputs and livestock prices were of several specialized sites. 
Table 1. Feed composition during the feedlot period ${ }^{1}$

\begin{tabular}{lcccccccccc}
\hline \multirow{2}{*}{ Ingredients } & & \multicolumn{4}{c}{$\%$ dry matter } & \multicolumn{1}{c}{ Cost, US\$ } \\
\cline { 3 - 8 } & $\mathrm{kg} \mathrm{DM}^{2}$ & $\mathrm{CP}^{3}$ & $\mathrm{TDN}^{4}$ & $\mathrm{Ca}^{5}$ & $\mathrm{P}^{6}$ & $\mathrm{Na}^{7}$ & $\mathrm{CF}^{8}$ & & kg & /day \\
\hline Corn silage & 5.00 & 7.5 & 63.0 & 0.33 & 0.25 & 0.12 & 33.0 & 0.12 & 2.114 \\
Soybean meal & 0.60 & 46.0 & 80.0 & 0.30 & 0.65 & 0.08 & 7.0 & 2.54 & 1.728 \\
Corn grain & 0.80 & 10.0 & 88.0 & 0.02 & 0.25 & 0.03 & 2.5 & 1.35 & 1.220 \\
Wheat meal & 1.60 & 17.0 & 72.0 & 0.12 & 1.10 & 0.03 & 10.2 & 1.70 & 3.098 \\
Salt & 0.01 & - & - & - & - & 40.00 & - & 0.33 & 0.003 \\
Soybean hulls & 1.00 & 13.0 & 76.0 & 0.80 & 0.22 & 0.05 & 25.0 & 1.20 & 1.360 \\
Dicalcium phosphate & 0.03 & - & - & 24.00 & 12.00 & - & - & 4.51 & 0.152
\end{tabular}

${ }^{1}$ Considering: average animal weight of $413.0 \mathrm{~kg}$, dry matter intake of $2,50 \%$ of live weight and average daily gain of $1,00 \mathrm{~kg} ;{ }^{2}$ total kilograms of dry matter; ${ }^{3}$ crude protein; ${ }^{4}$ total digestible nutrients; ${ }^{5}$ calcium; ${ }^{6}$ phosphorus; 7 sodium; ${ }^{8}$ crude fiber. US $\$ 2.99=$ RS 1,00 .

The indicators used to support the analysis process will be divided into three parts: the associates to the return, associates at the risk and finally the indicators of efficiency productive and economic. For classification of cost items, revenues and calculations of financial indicators, were utilized methodologies proposed by Kassai et al. ${ }^{(11)}$ and Souza and Clemente ${ }^{(10)}$, and to the indicators of efficiency, calculations proposed by Menegassi et al. ${ }^{(13)}$. The calculations performed for the indicators of each system are shown in table 2 .

The facility costs were estimated with static capacity as the total number of animals, and useful life than eleven years. The depreciation (facilities) was calculated for a planning horizon of eleven years, same period considered in the calculation of depreciation of machines, implements and equipment. Was performed the depreciation for all assets who remained on the property after a period of one year. For the cost of land opportunity, it was considered the possibility of annual lease at the equivalent value of $3 \%$ of the hectare. Already for the opportunity cost of invested capital calculation it was considered the sum of all costs without the opportunity costs multiplied by the minimum rate of attractiveness.

The sanitary control consisted of acquiring products for endo and ectoparasite and vaccines, both per animal dosage as indicated by the manufacturer. The feeding costs was obtained by implantation of the pastures and the confection of corn silage and concentrate on the property, beyond the supply of minerals and the use of machinery and equipment for the confection of the same. The costs with reproduction were composed by the acquisition of material to insemination, acquiring bulls and bonuses for the inseminators.

For pro labor costs it was fixed the value of five minimum wage per month. For costs estimates with hand labor (minimum wage+charges), was considered the need for one (1) farm worker/150 breeding stock, each three farm workers one (1) farm foreman, besides a diarist during the vacations of the effective workers. The taxes costs (IPVA, ITR and Fundesa) was calculated as suggested by the responsible organ. Other costs and revenues details can be found in Ávila ${ }^{(14)}$. 
Table 2. Calculation of indicators estimated by system

\begin{tabular}{|c|c|c|}
\hline Indicator & Unit & Equation \\
\hline Net present value & USS & $\begin{array}{l}=\sum_{\mathrm{i}=1}^{\mathrm{n}} \frac{\text { values }_{\mathrm{i}}}{(1+\mathrm{MRA})^{\mathrm{i}}} \text {, where } \mathrm{n}=\text { number of cash flows } \\
\text { and MRA }=\text { minimum rate of attractiveness }\end{array}$ \\
\hline Index benefit:cost (IB:C) & USS & $\begin{array}{l}=\text { Positive net present value/negative net present } \\
\text { values }\end{array}$ \\
\hline $\begin{array}{l}\text { Additional return on } \\
\text { investment }(\mathrm{ROI})\end{array}$ & $\%$ p.m. & $\begin{array}{l}=\mathrm{i}=\sqrt[\mathrm{n}]{\frac{\mathrm{FV}}{\mathrm{PV}}}-1 \text {, where } \mathrm{FV}=\text { future value is } \\
\text { represented by the IB: } \mathrm{C}, \mathrm{PV}=\text { present value, } \\
\mathrm{n}=\text { Periods and } \mathrm{i}=\text { interest rate, represents the } \\
\text { ROI }\end{array}$ \\
\hline Internal rate of return (IRR) & $\%$ p.m. & $\begin{array}{l}=-\mathrm{i}+\sum_{\mathrm{t}=1}^{\mathrm{n}} \frac{\mathrm{FC}_{\mathrm{t}}}{(1+\mathrm{IRR})^{\mathrm{t}}} \text {, where: } \mathrm{I}=\text { capital } \\
\text { investment in the zero date, } \mathrm{FCt}=\text { return at date } \\
\mathrm{t} \text { of the cash flow and } \mathrm{n}=\text { deadline for the } \\
\text { project analysis }\end{array}$ \\
\hline $\begin{array}{l}\text { Modified internal rate of } \\
\text { return (MIRR) }\end{array}$ & $\%$ p.m. & $\begin{array}{l}=\sum_{\mathrm{t}=0}^{\mathrm{n}} \frac{\mathrm{SC}}{(1+\mathrm{K})^{\mathrm{t}}}=\sum_{\mathrm{t}=0}^{\mathrm{n}} \frac{\mathrm{EC}_{\mathrm{t}}(1+\mathrm{K})}{(1+\mathrm{MIRR})^{\mathrm{n}}}, \\
\mathrm{n}=\text { deadline for the project analysis, } \mathrm{t}=\text { amount } \\
\text { of time that the capital was invested, } \\
\mathrm{SC}=\text { outings of cash, ECt=cost of the project } \\
\text { and } \mathrm{K}=\text { cost of the capital }\end{array}$ \\
\hline Discounted Payback (PBd) & Year & $\begin{array}{l}=((-1 * \text { negative net present value }) / \text { positive net } \\
\text { present value }) * \text { number of cash flows }\end{array}$ \\
\hline Birth rate & $\%$ p.p.c ${ }^{4}$ & $=$ Calves born $/$ cows in reproduction \\
\hline Mortality rate & $\%$ p.p.c & $=$ Loss of livestock/animals in the herd \\
\hline Offtake rate & $\%$ p.p.c & $\begin{array}{l}=\text { number of head sold/number of animals in } \\
\text { the herd }\end{array}$ \\
\hline Productivity per area & $\mathrm{kg} / \mathrm{ha}$ & $\begin{array}{l}=\text { Production of live weight in the year }(\mathrm{kg}) \\
\text { area occupied by the herd (ha) }\end{array}$ \\
\hline Gross income per hectare & USS & $=$ Revenue/surface of pastoral area \\
\hline Gross margin per hectare & US\$/ha & $=($ Revenue - total cost $) /$ surface of pastoral area \\
\hline Profitability & $\%$ & $=$ Gross margin $/$ revenue \\
\hline Cost per hectare & US\$/ha & $=$ Total cost $/$ total pastoral area \\
\hline Cost per kilogram sold & $\mathrm{US} \$ / \mathrm{kg}$ & $=$ Total cost $/$ total sold kilograms \\
\hline
\end{tabular}

\section{Results and Discussion}

The table 3 shows the technical and economic indicators for the studied systems. The males slaughter age and carcass weight obtained (249.75 and $243.27 \mathrm{~kg}$, respectively for feedlot and pastures) was sufficient for the $8 \%$ bonus offered to the quality standards of the breed. According to Vaz et al. ${ }^{(15)}$ 
crossing programs of beef cattle that seek improve carcass characteristics have been increasingly searched by the producers who seek maximum remuneration of their product, allying with slaughterhouses that have sought to encourage the production by offering bonuses of up to $10 \%$ of the price per kilogram of live animal that meet certain quality characteristics. Pacheco et al. ${ }^{(16)}$ comments that this is a common practice of the breed associations use this kind of marketing. In monetary values, in this study the bonus results in US\$ 0.28 more per kg of live animal, or an average of US\$ 127.82 per animal.

Table 3. Slaughter parameters and efficiency indicators estimated by system

\begin{tabular}{|c|c|c|c|c|}
\hline \multirow{2}{*}{ Slaughter parameters } & \multicolumn{2}{|c|}{ Feedlot } & \multicolumn{2}{|c|}{ Pasture } \\
\hline & Bonus & No bonus & Bonus & No bonus \\
\hline Slaughter weight (kg) & 462.5 & 462.5 & 450.5 & 450.5 \\
\hline Carcass yield (\%) & 54.0 & 54.0 & 54.0 & 54.0 \\
\hline Carcass weight $(\mathrm{kg})$ & 249.8 & 249.8 & 243.3 & 243.3 \\
\hline Bonus of quality ${ }^{1}(\%)$ & 8.0 & 0.0 & 8.0 & 0.0 \\
\hline Indicators of technical efficiency & Bonus & No bonus & Bonus & No bonus \\
\hline Pregnancy rate (\%) & 80.0 & 80.0 & 80.0 & 80.0 \\
\hline Birth rate $(\%)$ & 75.0 & 75.0 & 75.0 & 75.0 \\
\hline Weaning rate $(\%)$ & 71.0 & 71.0 & 71.0 & 71.0 \\
\hline Mortality rate $^{2}(\%)$ & 9.0 & 9.0 & 9.0 & 9.0 \\
\hline Bull/cows relation $^{3}$ & $1 / 110$ & $1 / 110$ & $1 / 123$ & $1 / 123$ \\
\hline \multicolumn{5}{|l|}{ Herd composition } \\
\hline Bulls & 3 & 3 & 2 & 2 \\
\hline Cull cows & 66 & 66 & 49 & 49 \\
\hline Breeding cows & 332 & 332 & 247 & 247 \\
\hline Males 0-1 year & 121 & 121 & 90 & 90 \\
\hline Females $0-1$ year & 121 & 121 & 90 & 90 \\
\hline Males $1-2$ years & 120 & 120 & 89 & 89 \\
\hline Females $1-2$ years & 70 & 70 & 52 & 52 \\
\hline Service horses & 8 & 8 & 6 & 6 \\
\hline Offtake rate $(\%)$ & 29.0 & 29.0 & 29.0 & 29.0 \\
\hline Productivity/area (kg live weight/ha) & 559.1 & 559.1 & 410.5 & 410.5 \\
\hline Indicators of economic efficiency & Bonus & No bonus & Bonus & No bonus \\
\hline Gross income/ha (US\$) & $2,489.98$ & $2,380.78$ & $1,857.23$ & $1,758.23$ \\
\hline Gross margin/ha (US\$) & -508.39 & -593.27 & 537,13 & 460,72 \\
\hline Profitability (\%) & -0.18 & -0.22 & -0.25 & -0.29 \\
\hline Cost/ha ${ }^{4}$ (USS) & $4,696.51$ & $4,664.84$ & $1,787.24$ & $1,770.85$ \\
\hline Cost $/ \mathrm{kg}^{5}$ (US\$) & 27.32 & 27.14 & 14.53 & 14.38 \\
\hline
\end{tabular}

Regarding to the indicators of technical efficiency, systems like the slaughter at 24 months have a higher dilution of costs due to present larger amount of animals of production (breeding cows and animals in finishing) and a smaller amount of animals of stock (calves and steers, heifers and bulls). 
Reproductive rates of $80 \%$ were observed with a productivity $559.1 \mathrm{~kg}$ and $410.5 \mathrm{~kg}$ per hectare, respectively to system in feedlot and pasture. These rates can be considered high, typical when observed biological viability of intensive systems. However, the offtake rate of $29 \%$ in both projects can be considered low, and is probably due this job do not consider the acquisition of animals to the systems, what consequently generated a small number of heads sold. By observing the intensive systems aiming at the increase of productive rates from a more global viewpoint, they have a faster production cycle, higher capital turnover and greater amount of production per area. The offtake rates can be explained due to the systems do not realize the buy of animals for rearing or finishing. It considered only the animals produced in the property. Due to this reason, the number of animals sold are low, mainly in times of higher forage allowance or feedlot.

The higher reproductive rates and lower mortality rates in addition to the food availability, allows to work with a greater number of heifers in the reproductive cycle, even knowing that this category has higher reproductive problems. Repetition of pregnancy, decreased milk production and lower maternal ability generally show bellow when compared to adult cows. In extensive or traditional systems, Beretta et al. ${ }^{(17)}$ cites that repetition of pregnancy in heifers are lower than $40 \%$ when there is exclusive use of native grassland as food.

In an indirect way, another factor contributing to the reproductive rates when intensifies the system is the genetic selection. Many extensive systems need to acquire females for the reproductive cycle, and this practice in addiction to be a practical of high-cost has strong influence of market oscillations $^{(9,18)}$. These systems make impossible the genetic selection, which as cites Jorge Júnior et al. ${ }^{(19)}$ becomes another factor that has a negative impact on the improvement of reproductive rates.

The indicators of economic efficiency allow us to follow the development of the system as a whole. The gross income per hectare shows the return of the system through the sale of animals by the area of pastoral surface, where the results indicate an increase in the value conform occurs the use of bonus (US\$ 2,489.98, US\$2,380.78, US\$ $1,857.23$ and US\$ $1,758.23$ for the system in feedlot with and without bonus and pasture with and without bonus, respectively).

Beretta et al. ${ }^{(20)}$ found that the production of live weight per hectare represents a quadratic increase according the increase in the birth rate, depending on age at first birth, age at slaughter and interaction between both, and also has direct influence in the gross margin. Perillat et al. ${ }^{(21)}$ comments that an increase in forage availability can increase the production margins by rising the stocking rate, the animals weight, or also both. Thus, systems as the intensive tend to have a higher income, but need higher investments, and so, alternatives as the use of bonus help decrease these differences of values.

Another factor that can be explained by these terms is the profitability, which expresses how much a product leaves from result in relation to its sale price and his production costs. Thus, the products from commercialization with bonus are most profitable $(-0.18 \%,-0.22 \%,-0.25 \%-0.29 \%$ for the system feedlot with and without bonus and pasture with and without bonus, respectively) than the same system without bonus, that means that even both systems have the same production cost by hectare and kilogram, as occurs the increase of the income, the cost are diluted among kilograms sold.

Thus, the use of bonus at the end of the production cycle becomes an important impact factor on the property, as it is a technology that has no costs, covers various categories of animals and still is an important monetary return at the end of the productive cycle and help with the increase of production 
indicators. Oiagen et al. ${ }^{(22)}$ found that operational costs increased with the introduction of technologies, indicating that, when the system is intensified significant increases occurs in variable costs, especially in feed. Missio et al. ${ }^{(1)}$ cite that the model of traditional system has proven economically inefficient, where the reduction in age of slaughter becomes a viable alternative, since it provides higher turnover from invested capital. Potter et al. ${ }^{(5,23)}$ further state that systems that make use of more intensive technology always show better results when compared to traditional systems because they offer a large range of technical and economic ways to be explored in order to get around the problems in productive alternatives.

So, investment projects as a rule, are represented in a cash flow, where can be analyzed in a more incisive way the results obtained or expected. Invest resources in a project means that is required the transfer of some capital and immobilize it in the activity, for a period of time, which is called the planning horizon. At the end of this period, it is expected that the project return or release resources equal to the initially immobilized, if there is investment in the project that presents the lower risk at a given time or situation ${ }^{(10)}$.

Table 4. Financial indicators estimated by system

\begin{tabular}{|c|c|c|c|c|}
\hline \multirow{2}{*}{ Indicators } & \multicolumn{2}{|c|}{ Feedlot } & \multicolumn{2}{|c|}{ Pasture } \\
\hline & Bonus & No bonus & Bonus & No bonus \\
\hline MRA $^{4}$ & 0.06 & 0.06 & 0.06 & 0.06 \\
\hline \multirow[t]{2}{*}{ Number of periods (years) } & 11 & 11 & 11 & 11 \\
\hline & \multicolumn{4}{|c|}{ Return indicators } \\
\hline $\mathrm{NPV}^{2}(\mathrm{US} \$)$ & $-2,446,235.05$ & $-2,795,575.93$ & $1,807,395.11$ & $1.490 .419,16$ \\
\hline IB $: \mathrm{C}^{3}$ & 0.40 & 0.35 & 6.53 & 5.21 \\
\hline \multirow[t]{2}{*}{$\mathrm{ROI}^{4}(\%)$} & -8.1 & -9.2 & 18.6 & 16.0 \\
\hline & \multicolumn{4}{|c|}{ Risk indicators } \\
\hline $\operatorname{IRR}^{5}(\%)$ & -22.3 & -25.2 & 53.2 & 40.5 \\
\hline $\operatorname{MIRR}^{6}(\%)$ & -8.8 & -10.0 & 27.1 & 24.3 \\
\hline Discounted payback (years) & 27.74 & 31.68 & 1.68 & 2.11 \\
\hline
\end{tabular}

The table 4 shows the financial indicators estimated by system. The minimum rate of attractiveness (MRA) is the best rate application of capital with low degree of risk ${ }^{(10)}$. In a simpler form is what would happen if the value of investment, such for example the intensification of livestock, was applied in a bank in order to obtain interest income. May be considered a margin of safety for investors. It was considered 0.06 corresponding to the income from savings accounts, according to Souza and Clemente ${ }^{(10)}$ suggestions .

A cash flow presents no doubt as to the values and their effective realization when performed in the form of deterministic analysis, namely, with the certainty of the indicators. Thus, the net present value (NPV) of the project must be verified. If this result is greater than zero, the project is considered viable. The NPV is the concentration of all values in the zero date, making the use of MRA as a discount ${ }^{(10)}$ and is an indicator of return. Therefore, the greater is the value of the NPV above zero, the higher will be the recuperation of the initial investment. 
Thus, we observe that the pasture system, it presents a monetary surplus, and the feedlot system has a negative return at the end of this horizon, and because of this shows up not viable as investment project. According to Souza and Clemente ${ }^{(10)}$ the value of NPV equal to zero indicates that the project recovers the initial investment cost and pays this cost if it had been applied to the MRA.

The IB:C, also called profitability index ${ }^{(11,26)}$ represents the proportion between revenues and costs, and in other words, how much it is expected return for each US\$1.00 invested ${ }^{(27)}$. So, to the project presents return it is necessary that IB:C>1. Once again, the feedlot system show negative results (US\$ 0.40 and US\$ 0.35 with and without bonus, respectively), returning only the third part of the invested capital, where the pasture system show surplus of US\$ 6.53 and US\$ 5.21 with and without the bonus application. Pacheco et al. ${ }^{(27)}$ also find negative values for the IB:C working with the finish of animals in feedlot. Mello et al. ${ }^{(4)}$ found a negative relation between the time of feed and the return of IB:C. These results show that the system in pasture presents a greater income flow than outcome flow compared to feedlot, probably due to the lower costs of production.

The ROI presents as a result the estimate of a profitability for an investment project, demonstrating in percentage terms the wealth generated ${ }^{(12)}$. It shows up positive for the system in pasture, where it will return $18 \%$ above the MRA, and shows that the feedlot project do not presents profitability.

The IRR, MIRR and the PBd represents risk indicators. They show the probability of an event and what the impact of this event on the project if it occurs. Regarding the internal rate of return (IRR), is the rate that makes the NPV of a cash flow equal to zero ${ }^{(10,11)}$ so it can be compared at the rate of MRA. So, the closer to one, is greater the risk of investing in the project. The pasture project presents a high risk of investment, what was expected considering the high wealth generated by the same, as was expected a low risk to the feedlot system due to this not be a profitable project.

The IRR also can be utilized as a return indicator and so can be compared to NPV method ${ }^{(10)}$. Kassai et al. ${ }^{(1)}$ cite that researchers prefer the NPV to the IRR due to is greater popularity among these professional, but the authors suggest a calculation of modified internal rate of return (MIRR). This way, it rescues the advantage of ease of interpretation of results in the form of rates for those who prefer the use of IRR.

The MIRR follow the logic of the indicators discussed above and poses greatest risk to the most profitable system, and from the perspective of return does not demonstrate viability for the feedlot system because it is negative result. Lastly, the discounted payback for the MRA shows the necessary time for the recuperation of the investment. The closer this value is to the final period of execution of the project, the greater the associated risk will be.

So the indicators showed up negative for the system in feedlot. Even if the IB:C and the payback shows up positive, these are not desirable values for an investment project. In other words, in the feedlot system, regardless of the use of the bonus, the NPV showed negative value with an index benefit:cost of \pm 0.37 , and a negative ROI, showing that the project will not return wealth. By the IRR and MIRR the project shows a low risk, and by the PBd, the system would take more than 30 years to pay herself without the use of bonus and 27 years with bonus, which is more than the double the time of planning horizon to return the initial investment and start generating some profits. These results indicate that the decision maker will get most successful investing in MRA. 
Even if the feedlot be a technique that are in growing increase due to a number of direct and indirect benefits, it is known that this is an expensive system mainly in the feeding supply. In order to obtain success, the producers use a high load of animals per hectare, to thereby perform a dilution of costs according to number of kilogram produced. Then, in this work as the acquisition of animals was not performed, the system in full cycle did not show viable from the perspective of investment project.

In relation to the pasture system, we observe that the NPV positive, an IB:C of 5.21 and 6.53 for the system without and with bonus, and despite presenting high risks, is provided a the return of the system after 2 and 1 year of investment, respectively. These results can be considered satisfactory, since according to Beretta et al. ${ }^{(20)}$, different factors make up a production system interact with each other, so that a point where you want to change affecting only one category may have effects on other categories on the herd, which will cause a difficulty of predicting the productive impact on the whole system. In resume, both pasture projects have their return in less time than the planning horizon time. These results indicate that the decision maker will get most successful investing in this project.

In his study, Melo Filho et al. ${ }^{(28)}$ calculated the costs and economic indicators of a system of full cycle and has found only positive results for the gross margin, where economic indicators that considered costs as depreciation and opportunity were negative, showing that the activity was not sustainable or attractive economically in the medium term. However, Simões et al. ${ }^{(25)}$ in their study evaluating the complete cycle concluded that the only the system of finishing showed negative results for some of the studied economic indicators. Simões and Moura ${ }^{(29)}$ observed that the profile of composition from costs and revenues of fattening period was distinguished from the other phases, which emphasized that the activity of fattening was the most competitive in terms of yield per hectare. Thus, the different phases result in variable degrees of profitability, where the findings of this study demonstrate that the return considering the project as a whole was not feasible for the system in full cycle utilizing feedlot, where the alternatives could be implemented in different phases in order to obtain different results of the process.

Table 5 shows the composition of total costs and total costs less depreciation. This is a factor of disagreement between the investment projects because some prefer to omit this information along with the opportunity costs. For these items, not necessarily require a monthly cash outlay, but, demonstrate the value of spending by the use of the goods that is required the investor saves so that, at the end of the useful life of an asset it already owns the total amount for the replacement of the items in the case of depreciation. In the case of opportunity costs, which are values that only demonstrate how much the investor would be remunerating or not if he chose to invest in other means instead of the project.

It is observed that the main cost center were with depreciation (27.40\%) and feeding supply (18.48\%) for feedlot and depreciation (28.24\%) and tax (21.99\%) the pasture systems when considering depreciation costs. When this is disregarded, the main costs was with feeding supply $(25.46 \%)$ and $\operatorname{tax}(21.99 \%)$ for feedlot and tax $(26.42 \%)$ and feeding supply $(23.14 \%)$ for the pasture systems. These results are in agreement with those found by some studies ${ }^{(9,24,27,30)}$ that mentions when disregarded the cost with buying animals, feeding becomes the main center of costs in feedlot systems.

The use of full cycles of production presents itself as an interesting alternative because the main center of expected cost is not applied because the animal is produced on the property. Thereby creating a lower risk to the system by the less dependence of market, which directly interfere in the 
viability of investments.

Table 5. Relative share of the items of cost in relation to the total cost and the total cost less the depreciation cost estimated by system

\begin{tabular}{|c|c|c|c|c|}
\hline \multirow[t]{2}{*}{ Variable } & \multicolumn{2}{|c|}{$\begin{array}{c}\text { In relation to total cost, } \\
\%\end{array}$} & \multicolumn{2}{|c|}{$\begin{array}{l}\text { In relation to the total } \\
\text { cost - depreciation, \% }\end{array}$} \\
\hline & Feedlot & Pasture & Feedlot & Pasture \\
\hline Health control ${ }^{1}$ & 1.08 & 1.37 & 1.49 & 1.90 \\
\hline Reproductive $^{2}$ & 1.12 & 1.28 & 1.55 & 1.78 \\
\hline Feeding supply ${ }^{3}$ & 18.48 & 16.60 & 25.46 & 23.14 \\
\hline Labor ${ }^{4}$ & 8.31 & 10.05 & 11.45 & 14.01 \\
\hline Other costs ${ }^{5}$ & 13.72 & 6.39 & 18.89 & 8.90 \\
\hline Depreciation 6 & 27.40 & 28.24 & - & - \\
\hline $\operatorname{Tax}^{7}$ & 15.96 & 18.96 & 21.99 & 26.42 \\
\hline Pro labor ${ }^{8}$ & 8.24 & 13.07 & 11.35 & 18.22 \\
\hline Opportunity cost of land ${ }^{9}$ & 0.02 & 0.03 & 0.03 & 0.04 \\
\hline Opportunity cost of invested capital ${ }^{10}$ & 5.66 & 4.01 & 7.80 & 5.59 \\
\hline Total & 100 & 100 & 100 & 100 \\
\hline
\end{tabular}

In the study of Resende Filho et al. ${ }^{(31)}$ the authors comment on the fixed capital tied up in activity is lower when compared with variable capital involved with the purchase of steers and spending on food and other production factors. Pacheco et al. ${ }^{(27)}$ found that the depreciation costs are only $9.8 \%$ when working on finishing. Thus, we observe an inversion in the results when we evaluate the full cycle against only one of the phases of production. This differentiation is mainly associated, as previously mentioned, to the full cycle have a higher number of idle categories when compared at finishing or rearing systems, which requires a greater infrastructure to keep the system functioning, which ultimately generating one bigger depreciation value over the planning horizon.

\section{Conclusions}

The financial indicators have show in the long term that the system in full cycle with finish at 24 months was feasible for the system in pasture, mainly to the lower feed costs. The higher costs with feeding supply contributed to the system in feedlot presents no return at the end of planning horizon. The use of bonus show as an favorable alternative to the increase of the revenues, with a view that can be applied to the systems without the need of specific monetary investments, increasing profitability and diluting costs. The main center of costs in the projects was with depreciation, feed supply and tax. 


\section{References}

1. Missio RL, Brondani IL, Freitas LS, Sachet RH, Silva JHS, Restle J. Desempenho e avaliação econômica da terminação de tourinhos em confinamento alimentados com diferentes níveis de concentrado na dieta. $\mathrm{R}$ Bras Zootec. [Internet]. 2009 [Accessed Jan. 17, 2015]; 38(7):1309-16. Available from: http://dx.doi.org/10.1590/S1516-35982009000700021

2. Lopes LS, Ladeira MM, Machado Neto OR, Silveira ARMC, Reis RP, Campos FR. Viabilidade econômica da terminação de novilhos Nelore e Red Norte em confinamento na região de Lavras-MG. Cienc Agrotec. [Internet]. 2009 [Accessed Jan. 17, 2015]; 38(7):774-80. Available from: http://www.scielo.br/pdf/cagro/v35n4/17.pdf

3. Millen DD, Pacheco RDL, Arrigoni MDB, Gaylean ML, Vasconcelos JT. A snapshot of management practices and nutritional recommendations used by feedlot nutritionists in Brazil. J Anim Sci. [Internet]. 2009 [Accessed Jan. 17, 2015]; 87(1):3427-39. Available from: https://dl.sciencesocieties.org/publications/jas/abstracts/87/10/3427

4. Mello RO, Resende FD, Queiroz AC, Faria MH, Oliveira AS, Siqueira GR. Bio-economicity of the finishing phase on feedlot of crossbred young bulls slaughtered at different body weights. R Bras Zootec. [Internet]. 2009 [Accessed Jan. 17, 2015]; 38(1):109-21. Available from: http://dx.doi.org/10.1590/S1516$\underline{35982009000100015}$

5. Pötter L, Lobato JFP, Mielitz Netto CGA. Produtividade de um modelo de produção para novilhas de corte primíparas aos dois, três e quatro anos de idade. R Bras Zootec. [Internet]. 1999 [Accessed Jan. 17, 2015]; 27(3): 613-19. Available from: http://www.sbz.org.br/revista/artigos/2078.pdf

6. Martins CEN, Quadros FLF, Bandinelli DG, Simões LFC, Kloss MG, Rocha MG. Variáveis morfogênicas de milheto (Pennisetum americanum) mantido em duas alturas de pastejo. Cienc Rural. [Internet]. 2005 [Accessed Jan. 17, 2015]; 35(1):174-80. Available from: http://dx.doi.org/10.1590/S0103$\underline{84782005000100028}$

7. Macari S, Rocha MG, Restle J, Pilau A, Freitas AK, Neves FP. Avaliação da mistura de cultivares de aveia preta (Avena strigosa Schreb) com azevém (Lolium multiflorum Lam.) sob pastejo. Cienc Rural. [Internet]. 2006 [Accessed Jan. 17, 2015]; 36(3):910-15. Available from: http://dx.doi.org/10.1590/S0103$\underline{84782006000300028}$

8. Rodrigues DA, Avanza MFB, Dias LGGG. Sobressemeadura de aveia e azevém em pastagens tropicais no inverno - revisão de literatura. Rev Cient Elet Med Vet. [Internet]. 2011 [Accessed Jan. 17, 2015]; 9(16). Available from: http://faef.revista.inf.br/imagens_arquivos/arquivos_destaque/Xuh4UcEksPD3TLT_2013-626-11-14-53.pdf

9. Restle J, Pacheco PS, Costa EC, Freitas AK, Vaz FN, Brondani IL et al. Apreciação econômica da terminação em confinamento de novilhos Red Angus superjovens abatidos com diferentes pesos. R Bras Zootec. [Internet]. 2007 [Accessed Jan. 17, 2015]; 36(4):978-86. Available from: http://www.scielo.br/pdf/rbz/v36n4/30.pdf

10. Souza A, Clemente A. Decisões financeiras e análise de investimentos. 6th ed. São Paulo, Brasil: Editora Atlas; 2009. 186p. (portuguese)

11. Kassai JR, Casanova SPC, Santos A, Assaf Neto A. Retorno de investimento: abordagens matemática e contábil do lucro empresarial. 3th ed. São Paulo, Brasil: Editora Atlas; 2007. 276p. (portuguese)

12. ABHB, Associação Brasileira de Hereford e Braford. Programa Silva de bonificação para carne Hereford 
e Braford. [Internet]. 2014 [Accessed Jan. 17, 2015]. Avaliable from: http://goo.gl/C7AxFb

13. Menegassi SRO, Canellas LC, Marques PR, Moojen FG, Azevedo EVT, Evangelista GT et al. Manejo de sistemas de cria em pecuária de corte. Guaíba, Brasil: Editora Agrolivros; 2013.168p. (portuguese)

14. Ávila MM. Viabilidade econômica de sistemas de produção de ciclo completo de bovinos de corte. [Dissertation]. Santa Maria (RS): Universidade Federal de Santa Maria, Brasil; 2015. (portuguese)

15. Vaz FN, Vaz RZ, Pascoal LL, Pacheco PS, Miotto FRC, Teixeira NP. Análise econômica, rendimentos de carcaça e dos cortes comerciais de vacas de descarte 5/8 Hereford 3/8 Nelore abatidas em diferentes graus de acabamento. Ci Anim Bras. [Internet]. 2012 [Accessed Jan. 17, 2015]; 13(3):338-45. Avaliable from: http://www.revistas.ufg.br/index.php/vet/article/view/17572/11963

16. Pacheco PS, Vaz FN, Restle J, Ávila MM, Olegário JL, Menezes FR et al. Deterministic economic analysis of feedlot Red Angus young steers: slaughter weights and bonus. Cienc Rural. 2014a [Internet]. 2014a [Accessed Jan. 17, 2015]. Avaliable from: http://dx.doi.org/10.1590/0103-8478cr20140631

17. Beretta V, Lobato JFP, Mielitz Netto, CG. Produtividade e eficiência biológica de sistemas de produção de gado de corte de ciclo completo no Rio Grande do Sul. R Bras Zootec. [Internet]. 2002 [Accessed Jan. 17, 2015]; 31(2):991-01. Avaliable from: http://dx.doi.org/10.1590/S1516-35982002000400023

18. Ferreira IC, Silva MA, Reis RP, Euclides Filho K, Figueiredo GR, Fridrich AB et al. Análise de sensibilidade da margem bruta da receita e dos custos do confinamento de diferentes grupos genéticos. Arq Bras Med Vet Zootec. [Internet]. 2005 [Accessed Jan. 17, 2015]; 57(1):93-103. Avaliable from: http://dx.doi.org/10.1590/S0102-09352005000100013

19. Jorge Júnior J, Cardoso VL, Albuquerque LG. Objetivos de seleção e valores econômicos em sistemas de produção de gado de corte no Brasil. R Bras Zootec. [Internet]. 2007 [Accessed Jan. 17, 2015]; 36(1):154958. Avaliable from: http://dx.doi.org/10.1590/S1516-3598200700070001

20. Beretta V, Lobato JFP, Mielitz Netto CGA. Produtividade e eficiência biológica de sistemas pecuários de cria diferindo na idade das novilhas ao primeiro parto e na taxa de natalidade do rebanho no Rio Grande do Sul. R Bras Zootec. [Internet]. 2001 [Accessed Jan. 17, 2015]; 30(4):1278-86. Avaliable from: http://www.scielo.br/pdf/rbz/v30n4/6037.pdf

21. Perillat BJ, Brown WJ, Cohen RDH. A risk efficiency analysis of backgrounding and finishing steers on pasture in Saskatchewan, Canada. Agric Syst. [Internet]. 2004 [Accessed Jan. 17, 2015]; 80:213-33. Avaliable from: http://www.sciencedirect.com/science/article/pii/S0308521X03001355

22. Oaigen RP, Barcellos JOJ, Christofari LF, Braccini Neto J, Oliveira TEO, Prates RR. Análise da sensibilidade da metodologia dos centros de custos mediante a introdução de tecnologias em um sistema de produção de cria. R Bras Zootec. [Internet]. 2009 [Accessed Jan. 17, 2015]; 38(6):1155-62. Avaliable from: http://dx.doi.org/10.1590/S1516-35982009000600025

23. Pötter L, Lobato JFP, Mielitz Netto CGA. Análises econômicas de modelos de produção com novilhas de corte primíparas aos dois, três e quatro anos de idade. R Bras Zootec. [Internet]. 2000 [Accessed Jan. 17, 2015]; 29(3):861-70. Avaliable from: http://www.scielo.br/pdf/rbz/v29n3/5835.pdf

24. Lopes MA, Magalhães GP. Análise da rentabilidade da terminação de bovinos de corte em condições de confinamento: um estudo de caso. Arq Bras Med Vet e Zootec. [Internet]. 2005 [Accessed Jan. 17, 2015]; 57(3):374-79. Avaliable from: http://dx.doi.org/10.1590/S0102-09352005000300016

25. Simões ARP, Moura AD, Rocha DT. Avaliação econômica comparativa de sistemas de produção de gado de corte sob condições de risco no Mato Grosso do Sul. Rev Econ Agron. [Internet]. 2006 [Accessed Jan. 17, 2015]; 5(1):51-72. Avaliable from: http://ageconsearch.umn.edu/bitstream/55172/2/Volume n3 07.pdf

26. Lapponi JC. Projetos de investimento na empresa. Rio de Janeiro, Brasil: Editora Elsevier; 2007. 488p. 
(portuguese)

27. Pacheco PS, Silva RM, Padua JT, Restle J, Taveira RZ, Vaz FN et al. Análise econômica da terminação de novilhos em confinamento recebendo diferentes proporções de cana-de-açúcar e concentrado. Sem Cien Agra. [Internet]. 2014b [Accessed Jan. 17, 2015]; 35(2):999-12. Avaliable from: http://dx.doi.org/10.5433/1679-0359.2014v35n2p999

28. Melo Filho GA, Costa FP, Corrêa ES, Pereira MA, Silva Netto FG. Custo de produção de gado de corte no estado de Rondônia. EMBRAPA-CNPGC. Comunicado Técnico, 92. Rondônia, [Internet] 2005 [Accessed Jan. 17, 2015]. 7p. [Internet]. Available from: http://www.cnpgc.embrapa.br/publicacoes/cot/pdf/COT92.pdf

29. Simões ARP, Moura AD. Análise de risco do desempenho econômico de um sistema de recria de gado de corte em regime de pastejo rotacionado. Rev Econ Agron. [Internet]. 2006 [Accessed Jan. 17, 2015] ;4(1):7597. Available from: http://www.sober.org.br/palestra/2/455.pdf

30. Pacheco PS, Restle J, Vaz FN, Freitas AK, Padua JT, Neumann M et al. Avaliação econômica da terminação em confinamento de novilhos jovens e superjovens de diferentes grupos genéticos. R Bras Zootec. [Internet]. 2006 [Accessed Jan. 17, 2015]; 35(1):309-20. Available from: http://dx.doi.org/10.1590/S1516$\underline{35982006000100039}$

31. Resende Filho MA, Braga MJ, Rodrigues RV. Sistemas de terminação em confinamento: Perspectivas para dinamização da cadeia produtiva da carne bovina em Minas Gerais. R Bras de Econ. [Internet]. 2001 [Accessed Jan. 17, 2015]; 55(1):107-31. Available from: http://dx.doi.org/10.1590/S0034$\underline{71402001000100005}$ 